\title{
Refining Previous Estimates of Groundwater Outflows from the Medina/Diversion Lake System, San Antonio Area, Texas
}

\section{Introduction}

In 2016, the U.S. Geological Survey (USGS), in cooperation with the San Antonio Water System, began a study to refine previously derived estimates of groundwater outflows from Medina and Diversion Lakes in south-central Texas near San Antonio. When full, Medina and Diversion Lakes (hereinafter referred to as the Medina/Diversion Lake system) (fig. 1) impound approximately 255,000 acre-feet and 2,555 acre-feet of water, respectively.

Most recharge to the Edwards aquifer occurs as seepage from streams as they cross the outcrop (recharge zone) of the aquifer (Slattery and Miller, 2017). Groundwater outflows from the Medina/Diversion Lake system have also long been recognized as a potentially important additional source of recharge. Puente (1978) published methods for estimating monthly and

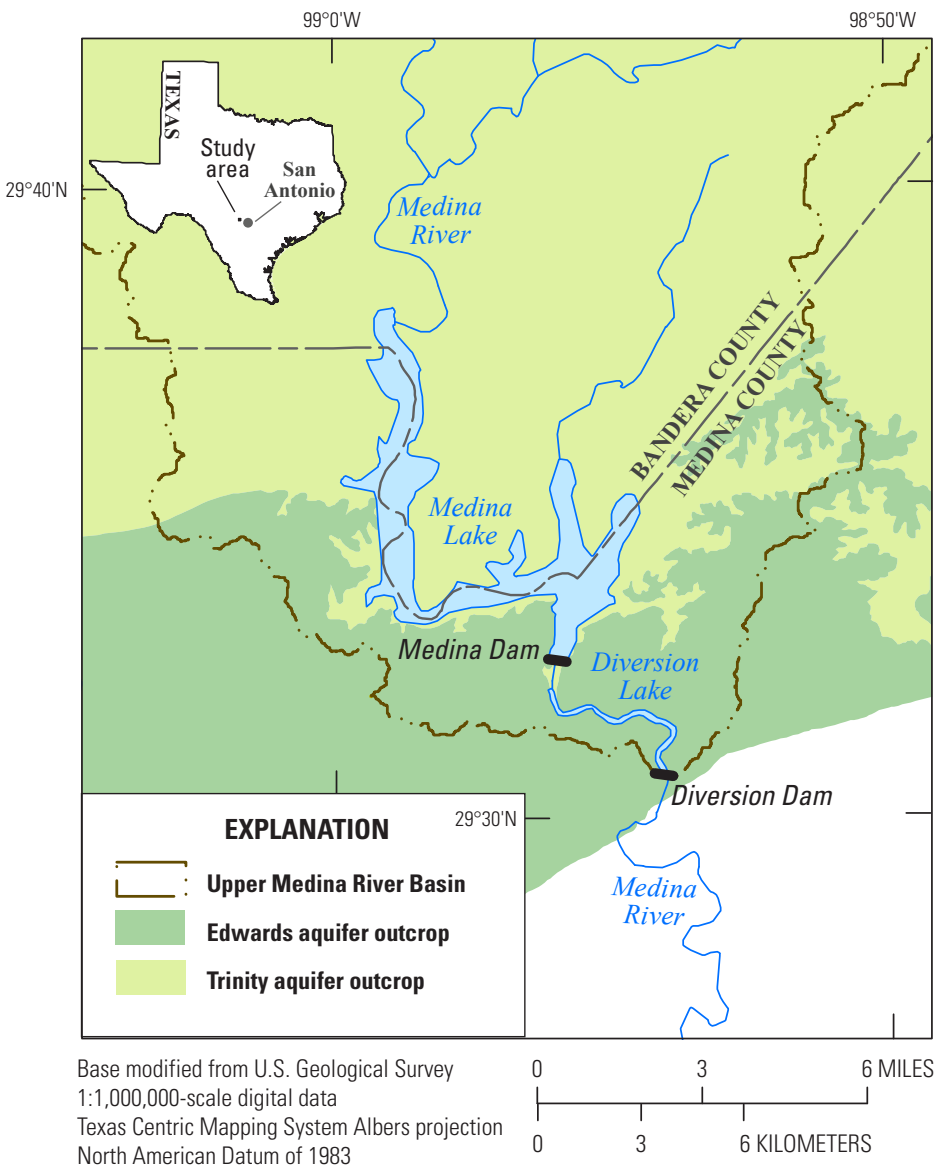

Figure 1. Locations of the study area and upper Medina River Basin, San Antonio area, Texas. annual estimates of the potential recharge to the Edwards aquifer from the Medina/Diversion Lake system. During October 1995-September 1996, the USGS conducted a study to better define short-term rates of recharge and to reduce the error and uncertainty associated with estimates of monthly recharge from the Medina/Diversion Lake system (Lambert and others, 2000). As a followup to that study, Slattery and Miller (2017) published estimates of groundwater outflows from detailed water budgets for the Medina/Diversion Lake system during 1955-1964, 1995-1996, and 2001-2002. The water budgets were compiled for selected periods during which time the waterbudget components were inferred to be relatively stable and the influence of precipitation, stormwater runoff, and changes in storage were presumably minimal. Linear regression analysis techniques were used by Slattery and Miller (2017) to assess the relation between the stage in Medina Lake and groundwater outflows from the Medina/Diversion Lake system.

\section{Statistical Reanalysis}

A statistical reanalysis of the relation between Medina Lake stage and groundwater outflows from the Medina/Diversion Lake system was completed in 2016 to improve upon the linear regressions analysis techniques used in the past. The statistical reanalysis of Medina Lake stage and groundwater outflow data (Slattery and Miller, 2017, fig. 11 and table 5) was done by using the R statistical software (version R-3.3.2) (R Core Team, 2016). All of the data and $\mathrm{R}$ scripts are available online as digital files (Asquith and Slattery, 2016).

The results of this additional analysis culminated in a new log-log weighted least-squares regression equation with prediction intervals, referred to as the preferred regression equation (fig. 2). The development of this regression equation was published as an appendix to Slattery and Miller (2017). The preferred regression equation fits the average groundwater outflows and average Medina Lake stage data better than the previously published regression equation (Slattery and Miller, 2017). When applying the preferred regression equation, it is important to consider the uncertainty associated with estimates of groundwater outflows for a given Medina Lake stage. Upper and lower bounds of 75- and 90-percent prediction intervals for the preferred regression equations (fig. 2) represent the upper and lower range or probable groundwater outflow values where the actual observed groundwater outflow is likely within the specified prediction interval either 75 or 90 percent of the time (Helsel and Hirsch, 2002). 


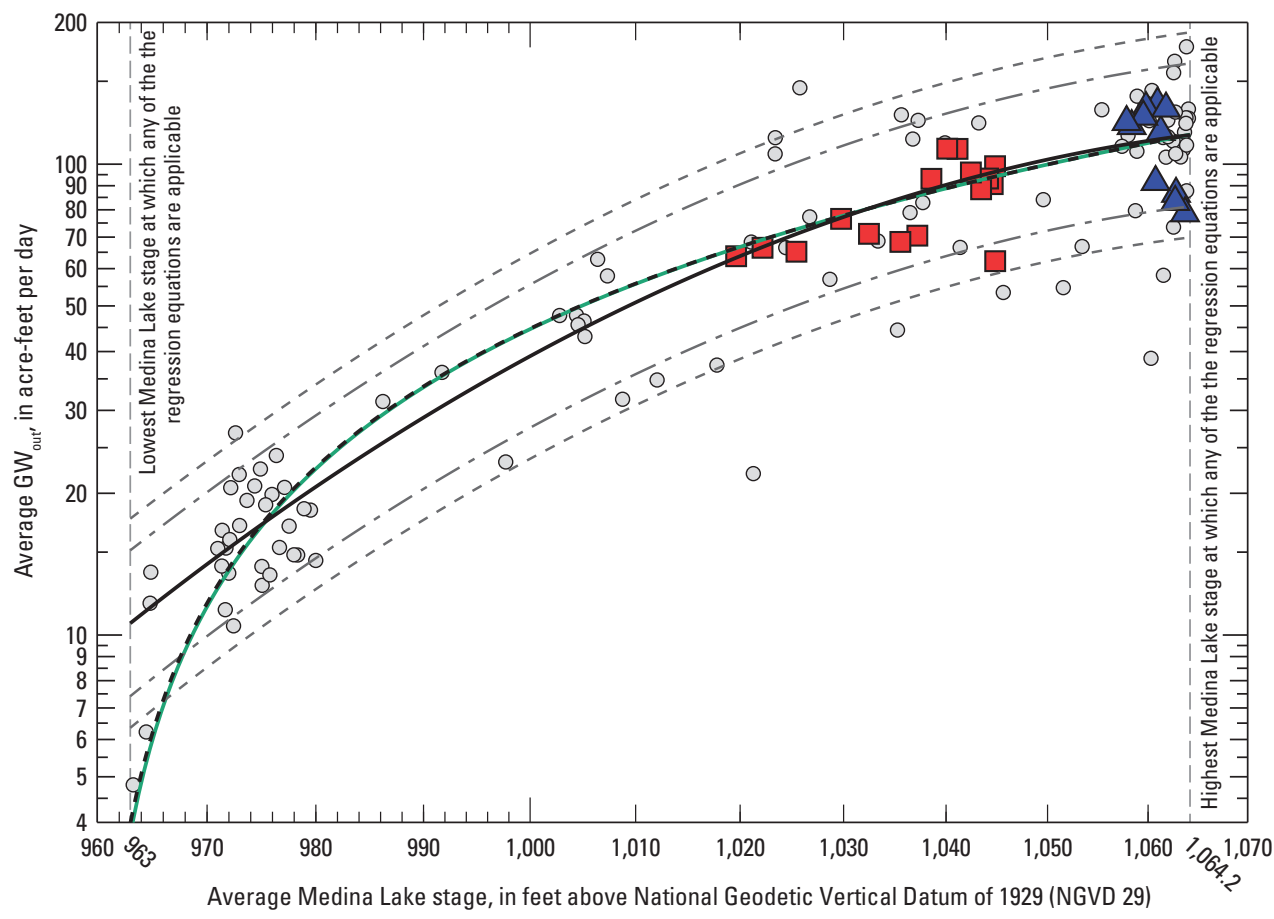

EXPLANATION

○

Average groundwater out term ( $\left.\mathrm{GW}_{\text {out }}\right)$ for various water-budget periods during 1955-1964

Average groundwater out term for various water-budget periods during 1995-1996

$\triangle$ Average groundwater out term for various water-budget periods during 2001-2002

Ordinary least-squares (OLS) regression in linear-linear transformation space

Weighted least-squares (WLS) regression in linear-linear transformation space

WLS regression in log-log space with retransformation bias correction to obtain $\mathrm{GW}_{\text {out }} 1$

Lower and upper bounds of 75-percent prediction intervals of $\log$-log WLS with retransformation bias correction

Lower and upper bounds of 90-percent prediction intervals of $\log -\log$ WLS with retransformation bias correction

'PREFERRED REGRESSION EQUATION

${ }_{\delta} G W_{\text {out }}=\delta \times 10^{\left\{2,413.26 \log _{10}(M L)-397.52\left[\log _{10}(M L)\right]^{2}-3,660.51\right\}}$

${ }_{\delta} G W_{\text {out }}=$ groundwater outflow from Medina/Diversion Lake system, in acre-feet per day

$M L=$ Medina Lake stage, in feet above NGVD 29 : $963 \leq M L \leq 1,064.2$ feet

$\delta=$ bias correction factor

$\delta= \begin{cases}1 & \text { if median } G W_{\text {out }} \text { is desired } \\ 1.042 & \text { if mean } G W_{\text {out }} \text { is desired }\end{cases}$

$\operatorname{adjRsq}=0.88$ adjusted $\mathrm{R}$-squared

$\mathrm{RSE}=0.13$ residual standard error (logarithmic, base-10 [ $\left.\log _{10}\right]$ )

Figure 2. Relation between average Medina Lake stage and average groundwater outflow (GW out $_{\text {) }}$ for water-budget periods 1955-1964, 1995-1996, and 2001-2002 (table 5 in Slattery and Miller, 2017) with a log-log weighted least-squares (log-log WLS) regression equation, and prediction intervals for the preferred regression equation (from Slattery and Miller, 2017).

\section{References Cited}

Asquith, W.A., and Slattery, R.N., 2016, Data and R script pertaining to Medina Lake stage and groundwater outflow, Medina and Diversion Lake system near San Antonio, Texas, 2016: U.S. Geological Survey data release, https:// doi.org/10.5066/F7ZS2TNF.

Helsel, D.R., and Hirsch, R.M., 2002, Statistical methods in water resources: U.S. Geological Survey Techniques of Water-Resources Investigations, book 4, chap. A3, accessed November 4, 2016, at http://pubs.usgs.gov/twri/twri4a3.

Lambert, R.B, Grimm, K.C., and Lee, R.W., 2000, Hydrology, hydrologic budget, and water chemistry of the Medina Lake area, Texas: U.S. Geological Survey Water-Resources Investigations Report 00-4148, 53 p.
Puente, Celso, 1978, Method of estimating natural recharge to the Edwards aquifer in the San Antonio area, Texas: U.S. Geological Survey Water-Resources Investigations Report 78-10, 34 p.

R Core Team, 2016, R-A language and environment for statistical computing: Vienna, Austria, R Foundation for Statistical Computing, accessed November 4, 2016, at http:// www.r-project.org/.

Slattery, R.N., and Miller, L.D., 2017, A water-budget analysis of Medina and Diversion Lakes and the Medina/Diversion Lake system, with estimated recharge to Edwards aquifer, San Antonio area, Texas (ver. 1.1, February 2017): U.S. Geological Survey Scientific Investigations Report 2004-5209, 41 p., https://doi.org/10.3133/sir20045209. 